\title{
Simultaneous Determination Of Sodium Benzoate And Sodium Cyclamate In Soft Drink Using High Performance Liquid Chromatography
}

Ariya Wijaya Putra, Asri Darmawati* \& Juniar Mochtar

Faculty of Pharmacy Universitas Airlangga, Surabaya

*Corresponding author: asridarmawati@yahoo.com

\begin{abstract}
Background: Sodium benzoate and sodium cyclamate are foods additives generally used as preservative and artificial sweeteners, respectively. Monitoring of sodium benzoate and sodium cyclamate need appropriate analytical method. Objective: The main objective of this study was to gain the optimum conditions for simultaneous determination of sodium benzoate and sodium cyclamate in soft drink by High Performance Liquid Chromatography. Methods: Measurement of the additives was performed in $\mu$-Bondapak RP18 column using methanol:phosphate buffer of pH 4 (42:58) as mobile phase with flow rate of $1 \mathrm{~mL} /$ minute. Results: It has shown that correlation coefficients $(r)$ of sodium benzoate and sodium cyclamate was 0.9997 and 0.9991 respectively. Recoveries of the two analyst were acceptable. Conclusions: Five out of nine samples tested contained sodium cyclamate higher than the recommended concentration. All sodium benzoate containing samples were within the recommended concentration.
\end{abstract}

Keywords: sodium benzoate, sodium cyclamate, soft drink, high performance liquid chromatography

\begin{abstract}
Abstrak
Pendahuluan: Natrium benzoat dan natrium siklamat adalah bahan pengawet dan pemanis yang umum ditambahkan ke dalam makanan dan minuman. Monitoring penggunaan kedua bahan ini memerlukan metode yang memenuhi persyaratan uji kualitatif dan kuantitatif. Tujuan: Tujuan penelitian ini adalah memperoleh kondisi optimum pada penentuan kadar natrium benzoat dan natrium siklamat dalam minuman ringan secara simultan dengan kromatografi cair kinerja tinggi (KCKT). Metode: Metode ini menggunakan kolom $\mu$-Bondapak RP18, fase gerak metanol:dapar fosfat $\mathrm{pH} 4$ (42:58) dengan laju alir $1 \mathrm{~mL} / \mathrm{menit}$. Hasil: Uji linieritas menunjukkan koefisien korelasi (r) natrium benzoat dan natrium siklamat masing-masing 0,9997 dan 0,9991. Uji perolehan kembali kedua analit ini memenuhi persyaratan. Kesimpulan: Lima dari 9 sampel yang diuji mengandung natrium siklamat melebihi batas yang dijinkan. Sedang kadar natrium benzoat dalam semua sampel memenuhi persyaratan.
\end{abstract}

Kata kunci: natrium benzoat, natrium siklamat, minuman ringan, kromatografi cair kinerjatinggi

\section{BACKGROUND}

Food additive is a substance or a mixture of substances in food but it isn't part of the raw material (BPOM, 2003). Food additives are used to maintain the quality of foods by improving texture, taste, stability also preserve the food or drink (BPOM, 2003). Sodium benzoate (Figure 1 (a)) is used as preservative, while sodium cyclamate (Figure 1 (b)) is an artificial sweetener in foods (BPOM, 2004). The Permitted concentration of sodium benzoate and sodium cyclamate in soft drink are $600 \mathrm{mg} / \mathrm{Kg}$ and $3 \mathrm{~g} / \mathrm{Kg}$, respectively (BPOM-RI, 1999). These two substances are mostly used in soft drink, as favorite beverage of non-alcoholic and carbonated or none carbonated.
Hence, monitoring of sodium benzoate and sodium cyclamate needs appropriate analytical methods for quality control purposes.

To date, the cyclamate analysis is still carried out using conventional gravimetric method. (Horwitz-, 2000). This technique takes a long time, tedious and the high risk of analysis error. Chromatographic technique offers more practical and easy method with a relatively shorter time consuming for analysis. One of the chromatographic methods is High Performance Liquid Chromatography (HPLC). Previous studies have reported the HPLC method for sodium cyclamate determination (Novelina, 2009). The HPLC method is also often used for determination of sodium benzoate 
(Hayun \& Aziza, 2004). On the other hands the determination of sodium cyclamate and sodium benzoate simultaneously, especially in Indonesian soft drinks, has not been reported.

The aim of this study was to obtain the optimum conditions for simultaneous determination of sodium benzoate and sodium cyclamate in soft drink samples from supermarket in Surabaya using HPLC.

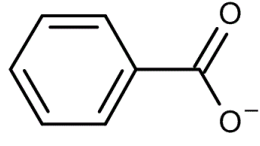

(a)

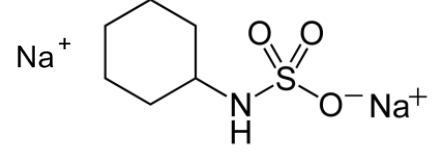

(b)
Figure 1. Molecule structures of sodium benzoate and sodium cyclamate

\section{MATERIALS AND METHODS}

\section{Materials}

Sodium Benzoate $\geq 99 \%$ purity (SIGMA), Sodium cyclamate Pharm. grade (Bernofarm), methanol pro HPLC (E. Merck), bi-distillated water (Ikapharmindo), distillated water (Brataco), $\mathrm{KH}_{2} \mathrm{PO} 4$ 99,5\% (SIGMA), dan $\mathrm{H}_{3} \mathrm{PO}_{4} 99 \%$ (E. Merck). Nine sodium benzoate and sodium cyclamate containing samples were collected from a supermarket located in Surabaya.

\section{Instrument}

High Performance Liquid Chromatography Agilent 1100 Series, with $\mu$-Bondapak RP 18 column completed with Diode Array Detector (DAD), Spectrophotometer UV-Vis Lambda EZ 201 Perkin Elmer, pH meter Fisher accumet model $230 \mathrm{~A}$.

\section{Sample preparation}

Sample was agitated in ultrasonic bath for 15 minutes for liberation of $\mathrm{CO}_{2}$ in the sample. Two milliliter of sample (A, C, E, H, I) or $3.0 \mathrm{~mL}$ of sample (F, G) was diluted quantitatively with bi-distillated water in $10 \mathrm{~mL}$ volumetric flash. Moreover, $2.0 \mathrm{~mL}$ of sample (B, D) was diluted quantitatively in $25 \mathrm{~mL}$ volumetric flash to obtain certain concentration. The diluted sample was filtered with Whatman filter paper of $0.2 \mu \mathrm{m}$ pores before being injected into HPLC apparatus.

\section{Operational conditions}

The sodium benzoate and sodium cyclamate standard concentrations range were 10 to $100 \mathrm{ppm}$ and 1200 to $6000 \mathrm{ppm}$, respectively. A mixture of methanol and phosphate buffer of $\mathrm{pH} 4.0 \pm 0.05$ was used as isocratic mobile phase. The optimum operational condition of HPLC was as follow: flow rate of mobile phase was $1 \mathrm{~mL} /$ minute, column pressure and temperature was 220 bar and $30{ }^{\circ} \mathrm{C}$, respectively. The loop volume was $20 \mu \mathrm{L}$.

\section{RESULTS AND DISCUSSION}

The spectra profile of sodium benzoate and sodium cyclamate showed that the maximum absorbance of sodium benzoate and sodium cyclamate were at $222 \mathrm{~nm}$ and $203 \mathrm{~nm}$, respectively (Figure 2).

Their spectra were crossing at the wavelength of $243 \mathrm{~nm}$. This wavelenght was then used as the wavelength detection of the two subtance examined.

Various composition of methanol and phosphate buffer of $\mathrm{pH} 4.0$ were used to obtain a good resolution (Rs) between sodium benzoate and sodium cyclamate.

The methanol and phosphate buffer of $\mathrm{pH} 4.0+0.05$ (42:58) separated the sodium benzoate peak (tR of 2.86 minutes) from the sodium cyclamate peak (tR of 6.50 minutes) by resolution (Rs) of 14.5 (Figure $3)$. This value fulfilled the acceptability for resolution that should be more than 1.5 for complete separation of two peaks (Watson D.G., 2012).

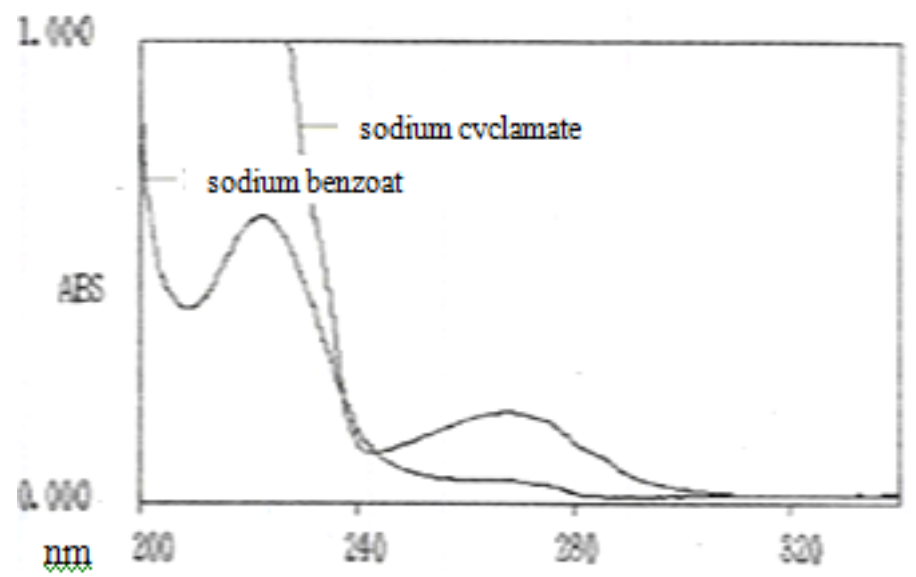

Figure 2. Overlay spectra of sodium benzoate (100 ppm) and sodium cyclamate (1200 ppm) 
Purity factor of sodium benzoate and sodium cyclamate standard peaks were 999.99 and 999.35 , respectively. It can be concluded that sodium benzoate and sodium cyclamate peaks chromatogram were pure and not overlapping one and the other or contaminated by another trace substance peak.

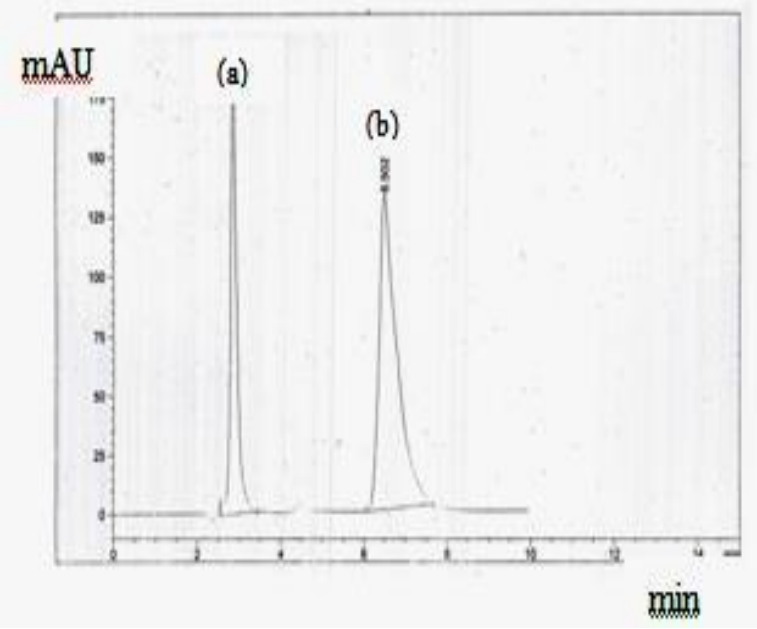

Figure 3. Chromatogram of $10 \mathrm{ppm}$ sodium benzoate standard (a) and 1200 ppm sodium cyclamate standard (b)

The chromatogram of sample $\mathrm{C}$ was showed in Figure 4. Based on the match factor (MF) spectra of the sodium benzoate and sodium cyclamate in the samples with their standard spectra (Table 1), the sodium benzoate and the sodium cyclamate peaks in the sample were identical with standard.

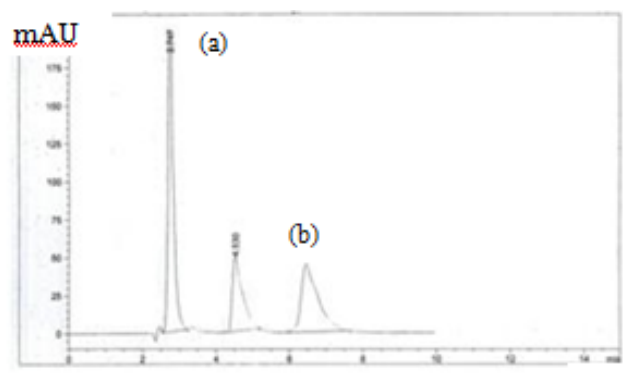

Figure 4. Chromatogram of sodium benzoate (a) and sodium cyclamate (b) in sample $\mathrm{C}$

Linearity of sodium benzoate in the concentration range of $10-100 \mathrm{ppm}$ was good. Regression equation of the sodium benzoate was $y=25.45 x+9.39(r=0.9997, V x o=0.40 \%)$.

Moreover, coefficient correlation of the sodium cyclamate in concentration range of (1200 - 6000) ppm was 0.9991, with regression equation of $\mathrm{y}=0.4845 \mathrm{x}+52.40,(\mathrm{Vxo}=4.9 \%)$.

Average recoveries of the sodium benzoate and sodium cyclamate standard using standard addition method were $(102.28 \pm 2.28) \%$ and $(101.62+1.58) \%$ (Table 2 and Table 3), respectively. These recoveries were fulfilled the AOAC recommendation (92 - $105 \%$ ) (AOAC, 2002).

Application of the HPLC method in nine samples with three replicates showed that five of nine samples contained sodium cyclamate higher than the recommended concentration, while all sodium benzoate containing sample within the recommended concentration (Table 4).

Table 1. The match factor of sodium benzoate and sodium cyclamate samples with their standard

\begin{tabular}{ccc}
\hline \multirow{2}{*}{ Sample } & \multicolumn{2}{c}{ Match Factor $^{*}$} \\
\cline { 2 - 3 } & sodium benzoate & sodium cyclamate \\
\hline A & 999.8770 & 999.9791 \\
B & 999.8986 & 999.9265 \\
C & 999.8180 & 999.9488 \\
D & 999.7893 & 999.6465 \\
E & 999.8761 & 999.9788 \\
F & 999.7734 & 999.9663 \\
G & 999.8097 & 999.9495 \\
H & 999.7988 & 999.8685 \\
I & 999.8094 & 999.9077 \\
\hline
\end{tabular}

*By electronic integrator of HPLC Agilent 1100 series software 
Table 2. Recovery of sodium benzoate standard in sample C

\begin{tabular}{ccccc}
\hline Replicate & $\begin{array}{c}\text { Standard added } \\
(\mathrm{ppm})\end{array}$ & $\begin{array}{c}\text { Total obtained } \\
(\mathrm{ppm})\end{array}$ & $\begin{array}{c}\text { Sodium benzoate } \\
\text { sample } \\
(\mathrm{ppm})\end{array}$ & $\begin{array}{c}\text { Recovery } \\
(\%)\end{array}$ \\
\hline 1 & 50.50 & 110.4 & 60.29 & 99.23 \\
2 & 50.50 & 112.4 & 60.29 & 103.19 \\
3 & 50.50 & 109.6 & 60.29 & 97.64 \\
1 & 60.60 & 121.2 & 60.29 & 101.51 \\
2 & 60.60 & 119.3 & 60.29 & 97.38 \\
3 & 60.60 & 121.9 & 60.29 & 101.67 \\
1 & 80.80 & 143.5 & 60.29 & 102.98 \\
2 & 80.80 & 139.9 & 60.29 & 98.53 \\
3 & 80.80 & 141.1 & 60.29 & 100.01 \\
\hline & Average & & 102.28 \\
& SD & & 2.28 \\
& CV
\end{tabular}

Table 3. Recovery of sodium cyclamate standard in sample C

\begin{tabular}{ccccc}
\hline Replicate & $\begin{array}{c}\text { Standard added } \\
(\mathrm{ppm})\end{array}$ & $\begin{array}{c}\text { Total obtained } \\
(\mathrm{ppm})\end{array}$ & $\begin{array}{c}\text { Sodium cyclamate } \\
\text { sample } \\
(\mathrm{ppm})\end{array}$ & $\begin{array}{c}\text { Recovery } \\
(\%)\end{array}$ \\
\hline 1 & 310.6 & 1464 & 1156 & 99.16 \\
2 & 310.6 & 1470 & 1156 & 101.09 \\
3 & 310.6 & 1467 & 1156 & 100.13 \\
1 & 372.6 & 1529 & 1156 & 100.11 \\
2 & 372.6 & 1528 & 1156 & 99.84 \\
3 & 372.6 & 1536 & 1156 & 101.99 \\
1 & 414.0 & 1579 & 1156 & 102.17 \\
2 & 414.0 & 1559 & 1156 & 97.34 \\
3 & 414.0 & 1566 & 1156 & 99.03 \\
\hline \multicolumn{4}{c}{ Average } \\
5
\end{tabular}


Table 4. Concentrations of sodium cyclamate and sodium benzoate in sample

\begin{tabular}{|c|c|c|c|c|c|}
\hline $\begin{array}{l}\text { Kode } \\
\text { Sample }\end{array}$ & $\begin{array}{c}\text { Sample } \\
\text { Performance }\end{array}$ & $\begin{array}{c}\text { Sodium } \\
\text { cyclamate/bottle }\end{array}$ & $\begin{array}{c}\text { Sodium } \\
\text { cyclamate/Kg }\end{array}$ & $\begin{array}{c}\text { Sodium } \\
\text { benzoate/bottle }\end{array}$ & $\begin{array}{c}\text { Sodium } \\
\text { benzoate/Kg }\end{array}$ \\
\hline & Soft drink & & & & \\
\hline A & $200 \mathrm{~mL} /$ bottle & $4087 \mathrm{mg} / 200 \mathrm{~mL}$ & $20435 \mathrm{mg} / \mathrm{Kg}^{*}$ & $66.20 \mathrm{mg} / 200 \mathrm{~mL}$ & $331 \mathrm{mg} / \mathrm{Kg}$ \\
\hline B & $\begin{array}{c}\text { Syrup } \\
300 \mathrm{~mL} / \text { bottle }\end{array}$ & $6125 \mathrm{mg} / 300 \mathrm{~mL}$ & $20417 \mathrm{mg} / \mathrm{Kg}$ & $323.6 \mathrm{mg} / 300 \mathrm{~mL}$ & $1078 \mathrm{mg} / \mathrm{Kg}$ \\
\hline $\mathrm{C}$ & $\begin{array}{c}\text { Soft drink } \\
190 \mathrm{~mL} / \mathrm{bottle}\end{array}$ & $1008 \mathrm{mg} / 190 \mathrm{~mL}$ & $5305 \mathrm{mg} / \mathrm{Kg}^{*}$ & $56.30 \mathrm{mg} / 190 \mathrm{~mL}$ & $296 \mathrm{mg} / \mathrm{Kg}$ \\
\hline $\mathrm{D}$ & $\begin{array}{c}\text { Syrup } \\
630 \mathrm{~mL} / \mathrm{bottle}\end{array}$ & $724.1 \mathrm{mg} / 630 \mathrm{~mL}$ & $1149 \mathrm{mg} / \mathrm{Kg}$ & $574.2 \mathrm{mg} / 630 \mathrm{~mL}$ & $911 \mathrm{mg} / \mathrm{Kg}$ \\
\hline E & $\begin{array}{c}\text { Soft drink } \\
200 \mathrm{~mL} / \text { bottle }\end{array}$ & $2898 \mathrm{mg} / 200 \mathrm{~mL}$ & $14490 \mathrm{mg} / \mathrm{Kg}^{*}$ & $67.18 \mathrm{mg} / 200 \mathrm{~mL}$ & $335 \mathrm{mg} / \mathrm{Kg}$ \\
\hline $\mathrm{F}$ & $\begin{array}{c}\text { Tea } \\
200 \mathrm{~mL} / \text { bottle }\end{array}$ & $236.2 \mathrm{mg} / 200 \mathrm{~mL}$ & $1181 \mathrm{mg} / \mathrm{Kg}$ & $55.91 \mathrm{mg} / 200 \mathrm{~mL}$ & $279 \mathrm{mg} / \mathrm{Kg}$ \\
\hline G & $\begin{array}{c}\text { Soft drink } \\
180 \mathrm{~mL} / \mathrm{bottle}\end{array}$ & $321.6 \mathrm{mg} / 180 \mathrm{~mL}$ & $1787 \mathrm{mg} / \mathrm{Kg}$ & $49.67 \mathrm{mg} / 180 \mathrm{~mL}$ & $275 \mathrm{mg} / \mathrm{Kg}$ \\
\hline $\mathrm{H}$ & $\begin{array}{c}\text { Soft drink } \\
175 \mathrm{~mL} / \mathrm{bottle}\end{array}$ & $2504 \mathrm{mg} / 175 \mathrm{~mL}$ & $14308 \mathrm{mg} / \mathrm{Kg}^{*}$ & $93.63 \mathrm{mg} / 175 \mathrm{~mL}$ & $535 \mathrm{mg} / \mathrm{Kg}$ \\
\hline I & $\begin{array}{c}\text { Soft drink } \\
200 \mathrm{~mL} / \text { bottle }\end{array}$ & $3131 \mathrm{mg} / 200 \mathrm{~mL}$ & $15655 \mathrm{mg} / \mathrm{Kg} *$ & $37.60 \mathrm{mg} / 200 \mathrm{~mL}$ & $188 \mathrm{mg} / \mathrm{Kg}$ \\
\hline
\end{tabular}

Note: $*$ Samples that were containing sodium cyclamate more than permitted concentration.

Assumption: syrup B or D were diluted ten times before consumption

\section{CONCLUSION}

The optimum condition for simultaneous determination of the sodium benzoate and sodium cyclamate by HPLC was selective, linear, accurate and precise.

The concentration range of the sodium benzoate and sodium cyclamate in samples, were $188-1078 \mathrm{mg} / \mathrm{Kg}$ and $1149-20435 \mathrm{mg} / \mathrm{Kg}$, respectively. Some of these samples contain sodium cyclamate more than permitted concentration. Nevertheless, all sodium benzoate containing samples were within the recommended concentration.

\section{REFERENCES}

AOAC International. (2002). AOAC Guidelines for Single Laboratory Validation of Chemical Methods for Dietary Supplements and Botanicals. Rockville, MD, USA; 18-21.

BPOM-RI. (1999). Peraturan Menteri Kesehatan

RI. No.1168/MENKES/PER/X/1999 tentang Perubahan Atas Permenkes No.722/ MENKES/PER/V/1988 tentang Bahan Tambahan Makanan. Jakarta: DepKes RI.

BPOM. (2003). Bahan Tambahan Pangan

Direktorat Surveilan dan Penyuluhan
Keamanan Pangan Deputi III. Jakarta: BPOM RI.

BPOM RI. (2004). Keputusan Kepala Badan Pengawas Obat dan Makanan Republik Indonesia No. HK.00.05.5.1.4547 tentang Persyaratan Penggunaan Bahan Tambahan Pangan Pemanis Buatan dalam Produk Pangan. Jakarta: Badan POM RI.

Hayun, H. Y. \& Aziza, C. N. (2004). Penetapan Kadar Sakarin, Asam Benzoat, Asam Sorbat, Kofeina, dan Aspartam di dalam Minuman Ringan Bersoda secara Kromatografi Cair kinerja Tinggi. Majalah Ilmu Kefarmasian; l(3); 148-159.

Horwitz, W. (2000). Official Methods of analysis of AOAC, $17^{\text {th }}$ Ed. Maryland, USA.

Novelina, Y. S., Sutanto \& Fatimah, A. (2009). Validasi Metode Analisis Penetapan Kadar Senyawa Siklamat dalam Minuman Ringan. Prosiding PPI Standardisasi; 1-10.

Watson, D. G. (1999). Pharmaceutical Analysis: A Textbook for Pharmacy Student and Pharmaceutical Chemists. London: Churchill Livingstone. 